\title{
KORELASI ANTARA MOTIVASI BERPRESTASI DAN KETERAMPILAN PRESENTASI PADA MAHASISWA PENDIDIKAN BAHASA INGGRIS FAKULTAS ILMU KEGURUAN DAN PENDIDIKAN UNIVERSITAS PEKALONGAN
}

\author{
Rizka Hayati*, Desyarini Puspita Dewi \\ Fakultas Keguruan dan Ilmu Pendidikan Universitas Pekalongan \\ J1 Sriwijaya No.3 Pekalongan \\ Korespondensi : rizkalinguistik@gmail.com
}

\begin{abstract}
Presentation skills are important skills for students of English education department. As a teacher candidate, English Education students need to have good and clear explanatory skills. However, not all students of English education of Unikal have good presentation skills. According to various previous studies, many factors influence presentation skills, one of which is achievement motivation. Motivation as a strong impulse from within a person that will rise the spirit of progress and success. From the reasons mentioned above, the researcher will conduct a correlation study between presentation skills and achievement motivation to determine whether there is a relationship between the two variables, and find out how strong the relations between the two variables are. The research method used in this study is a correlation study. The variables analyzed were presentation skills and achievement motivation. The subjects in this study were the English education students of UNIKAL. The instrument used is the scale of achievement motivation and presentation test. The results of the analysis state that there is a medium relationship between achievement motivation and presentation skill. This can be seen from the $r$ value of 0.413 . the $r$ value indicates the moderate strength of the relationship. From these values it can be concluded that there is a positive correlation between the two variables which means the higher the achievement motivation, the higher the presentation skills possessed.
\end{abstract}

Keywords : Correlation, Achievement motivation, Presentation skill

\begin{abstract}
ABSTRAK
Ketrampilan presentasi adalah ketrampilan yang penting untuk dimiliki oleh mahasiswa jurusan pendidikan bahasa inggris. Sebagai seorang calon guru, mahasiswa bahasa inggris tentunya dituntut untuk memiliki kemampuan menjelaskan yang baik dan jelas. Akan tetapi tidak semua mahasiswa pendidikan bahasa inggris Universitas Pekalongan memiliki ketrampilan presentasi yang baik. Menurut berbagai penelitian sebelumnya, banyak faktor yang mempengaruhi ketrampilan presentasi, salah satunya adalah motivasi berprestasi. Motivasi sebagai suatu dorongan kuat dari dalam diri seseorang akan memunculkan semangat untuk maju dan berhasil. Dari alasan tersebut diatas, maka peneliti akan melakukan studi korelasi antara ketrampilan presentasi dan motivasi berprestasi untuk mengetahui ada tidaknya hubungan antara kedua variable tersebut, serta mencari tau seberapa kuat hubungan kedua variable tersebut. Metode penelitian yang dipakai dalam penelitian ini adalah studi korelasi. Variable yang dianalisis adalah ketrampilan presentasi dan motivasi berprestasi. Subjek dalam penelitian ini adalah mahasiswa Pendidikan Bahasa Inggris FKIP UNIKAL. instrument yang digunakan adalah skala motivasi berprestasi dan tes kemampuan presentasi. Hasil analisis menyatakan bahwa terdapat hubungan yang kuat antara motivasi berprestasi dan ketramnpilan berprestasi. hal ini dapat dilihat dari nilai $r$ sebesar 0.413 . nilai $r$ tersebut menunjukkan kekutan hubungan yang sedang. Dari nilai tersebut dapat disimpulkan bahwa terdapat korelasi postif antara kedua variable yang berarti semakin tinggi motivasi berprestasi, semakin tinggi ketrampilan presentasi yang dimiliki.
\end{abstract}

Kata Kunci : Korelasi, ketrampilan berprestasi, motivasi berprestasi 


\section{PENDAHULUAN}

Terampil berbahasa Inggris merupakan hal yang wajib dimiliki oleh calon guru bahasa inggris. Namun demikian, pada kenyataannya, para mahasiswa bahasa inggris banyak yang belum menguasai bahasa inggris. Banyak faktor yang dapat mempengaruhi penguasaan bahasa Inggirs. Faktor-faktor tersebut contohnya adalah faktor psikologis, teknis, dan lingkungan. Faktor psikologis yang mempengaruhi sebagai contoh adalah motivasi, niat, dan kepercayaan diri. Sedang faktor teknis terkait pengetahuan dasar bahasa Inggris dan ketrampilan dalam menggunakan bahasa inggris. Faktor lingkungan terkait suasana belajar, cara mengajar guru atau dosen, teman belajar, serta lingkungan sosial.

Hermayawati (2010) menjelaskan bahwa permasalahan-permasalahan atau kesulitan yang dihadapi mahasiswa dalam belajar bahasa Inggris adalah : 1) rendahnya minat (motivasi) belajar karena pembelajara tidak menyukai bahasa Inggris; 2) Memiliki minat (motivasi) untuk belajar tetapi memiliki pengetahuan dasar bahasa inggris yang kurang; 3) Memiliki motivasi, memiliki pengetahuan dasar bahasa inggris akan tetapi tidak adanya dukungan dari lingkungan; 4) Memiliki motivasi yang cukup akan tetapi terkendala tidak ingat konsep dasar yang sudah dipelajari; 5) memiliki motivasi belajar tinggi tetapi tidak memiliki kesempatan belajar atau kesempatan balajar yang terlalu singkat.

Banyak usaha yang sudah dilakukan untuk mengatasi permasalahan-permasalahn yang dihadapi dalam belajar bahasa inggris, salah satunya adalah dengan mengupayakan faktor teknis dan menciptakan lingkungan yang mendukung. Dengan mengupayakan faktor teknis dan lingkungan harapannya akan dapat meningkatkan faktor internal seperti motivasi dan minat. Faktor internal yang perlu ditumbuhkan adalah motivasi. Motivasi merupakn faktor yang sangat penting dalam belajar. Alderman (2004) menyebutkan bahwa motivasi dalam diri seseorang memiliki 3 fungsi, yaitu mengaktifkan perilaku, mengarahkan perilaku, dan mengatur konsisensi perilaku meraih tujuan yang diharapkan. Dari kutipan tersebut dapat disimpulkan bahwa motivasi sangat penting karena dapat mengubah perilaku sesorang.

(Grolnick, Gurland, Jacob, \& Decourcey, 2002) menjelaskan bahwa motivasi yang benar-benar bisa menjadi energi penggerak yang kuat bagi seseorang adalah motivasi intrinsic. Setiap individu mempunyai motivasi intrinsik yang berfungsi untuk mengasah kemampuan, mengembangkan keterampilan, menguasai lingkungan baik internal dan eksternal. Motivasi intrinsik dalam diri individu akan berkembang dengan baik ketika motivasi tersebut bertemu dengan lingkungan yang mendukung, adanya stimulus, dan tantangan yang optimal. Motivasi instrinsik dapat dioptimalkan dengan cara menjadikan individu memiliki inisiatif atas perilakunya sendiri, menyadarkan bahwa dirinya sebagai individu selalu memiliki pilihan, dan merasa bertanggung jawab atas segala konsekuensi dari perilakunya.

Sesorang yang memiliki motivasi intrinsic yang tinggi juga akan memiliki motivasi berprestasi yang tinggi pula. Seseorang yang memiliki motivasi berprestasi yang tinggi biasanya dia akan memiliki pengetahuan dan ketrampilan yang baik pula. Mc Clelland (1987) menjelaskan bahwa motivasi beprestasi merupakan suatu dorongan atau keinginan untuk mencapai keberhasilan dalam situasi bersaing berdasarkan suatu keunggulan tertentu. Seseorang dengan motivasi berprestasi tinggi akan mengerahkan seluruh sumber daya yang ia miliki untuk mencapai hasil yang diinginkan dan sebuah 
keberhasilan, termasuk dalam keberhasilan dalam menguasai ilmu pengetahuan dan ketrampilan.

Selain dituntut untuk memiliki motivasi, calon guru juga dituntut untuk mahir dalam hal presentasi. Ketrampilan presentasi menjadi hal yang wajib dimiliki karena salah satu tugas guru adalah mengajarkan (mempresentasikan) materi kepada siswanya. Ketrampilan presentasi yang bagus dan jelas akan membantu siswa dalam memahami materi yang diajarkan. Presentasi menjadi salah satu faktor yang perlu diperhitungkan dalam hal pengajaran.

Ketrampilan presentasi adalah sebuah ketrampilan untuk menyampaikan dan mempresentasikan sesuatu kepada orang lain. Ketrampilan ini perlu untuk dimiliki siapapaun tak terkecuali oleh calon guru bahasa inggris. Memiliki ketrampilan presentasi yang bagus dapat mendukung kemampuan sesorang alam segala bidang. Sebagai seorang calon guru, ketrampilan presentasi penting untuk dimiliki tidak hanya dalam dunia pengajaran saja, akan tetapi penting juga sebagai tambahan keterampilan mereka agar siap berdaya saing di dunia global terlebih dengan adanya MEA, tuntutan untuk memiliki kemampuan dan keterampilan yang baik menjadi sangat tinggi.

Presentasi yang baik dan jelas akan membantu siswa menyerap materi yang diberikan. Ketarmpilan ini tidak hanya harus dimiliki oleh guru akan tetapi calon guru atau mahasiswa keguruan pun diharapkan mempunyai hal tersebut. keterampilan presentasi harus dipelajari dan dimiliki sedini mungkin oleh para calon guru sehingga kelak ketika mereka menghadapi dunia kerja sebagai seorang guru profesional, mereka sudah mempunyai keterampilan yang cukup memadai.

\section{RUMUSAN MASALAH}

Dari paparan diatas dapat terlihat adanya hubungan antara motivasi berprestasi dan ketrampilan presentasi. Dari fenomena inilah peneliti tertarik untuk mengadakan penelitian lebih lanjut mengenai seberapa erat tingkat keterikatan atau hubungan antara motivasi berprestasi dan ketrampilan presentasi. Dengan demikian, tujuan penelitian ini adalah untuk mengetahui apakah ada hubungan antara motivasi berprestasi dan ketarmpilan presentasi, bagaimana arah hubungan antara kedua variable tersebut, serta seberapa erat hubungan tersebut.

\section{HIPOTESIS KAJIAN}

Ho : Terdapat hubungan positif antara motivasi berprestasi dan ketrampilan presentasi, artinya bahwa jika seseorang memiliki level motivasi yang tinggi maka skor ketrampilan presentasi akan tinggi.

Ha : Terdapat hubungan negatif antara motivasi berprestasi dan ketrampilan presentasi, artinya bahwa jika seseorang memiliki level motivasi yang tinggi maka skor ketrampilan presentasi akan rendah.

\section{TINJAUAN PUSTAKA}

\subsection{Pengertian Motivasi Berprestasi}

Mc Clelland (1987) menyebutkan bahwa motivasi beprestasi merupakan suatu keinginan untuk mencapai keberhasilan dalam situasi bersaing berdasarkan suatu keunggulan tertentu. Motivasi berprestasi dikembangkan dari teori kebutuhan bahwa pada dasarnya setiap orang memiliki 3 kebutuhan dalam dirinya. Ketiga kebutuhan tersebut adalah kebutuhan untuk berprestasi (need for achievement), 
kebutuhan untuk berkuasa (need for power), dan kebutuhan untuk berafiliasi atau berhubungan (need for affiliation).

Achievement motivation berkaitan tentang usaha keras untuk menjadi kompeten (Dweck \& Molden, 2005). Ada dua alasan yang menjadikan seseorang ingin menjadi kompeten. Pertama, setiap manusia dilahirkan memiliki hasrat untuk menjadi kompeten. Dengan memiliki kompetensi, manusia bertahan dalam kehidupannya. Kesadaran tersebut bertambah seiring perkembangan sehingga orang menjadi lebih menghargai pentingnya belajar dan bertumbuh. Alasan kedua bahwa setiap orang ingin menjadi kompeten karena hal tersebut menjadi bagian dari konsep diri seseorang. Manusia menilai dirinya sendiri dari kompetensi yang dimiliki dan adanya penghargaan dari orang lain. Dengan demikian, achievement motivation didorong oleh adanya penghargaan terhadap belajar menjadi kompeten (learning goals) dan menguji kompetensi (performance goals). Konsep tersebut dikembangkan dari "self-theories" yang menganggap bahwa seseorang menetapkan suatu keterampilan atau sifat tertentu sebagai kualitas personalnya.

\subsection{Faktor yang Mempengaruhi Motivasi Berprestasi}

Grolnick, dkk (2002) menyebutkan adanya "self-determination" yang merupakan tingkat sejauhmana individu menganggap dirinya memiliki otonomi untuk memilih aksi maupun reaksi atau merasa dikontrol oleh sesuatu dari luar dirinya. Konsep dalam kajian motivasi dikenal istilah "locus of control". Mereka yang memiliki pusat kontrol pada diri sendiri akan memandang kesuksesan maupun kegagalan atas hasil dari perbuatan sendiri. Mereka yang menganggap segala perilaku dirinya ditentukan oleh sesuatu dari luar disebut memiliki pusat kontrol eksternal. Tingkat motivasi instrinsik tergantung pada self-determination individu. Mereka yang memiliki self-determination rendah akan memiliki motivasi instrinsik yang rendah pula. Dengan demikian, rentang dari motivasi intrinsik sampai motivasi ekstrinsik dipandang sebagai kontinum atas tingkat self-determination individu.

\subsection{Ketrampilan Presentasi}

Ketrampilan presentasi adalaha ketrampilan dalam menyampaikan sesuatu kepada orang lain. Ketrampilan ini termasuk dalam ketrampilan berkomunikasi, khususnya komunikasi publik. Oleh karena itu, tentu ada bnayak faktor yang mempengaruhi presentasi sebagai salah satu bentuk komunikasi. Saat seseorang berkomunikasi Rahmawati menyatakan bahwa sesorang haruslah menguasai pesan, mempunyai ketrampilan untuk berkomunikasi, dan juga menjaga etika atau sopan.

Lebih lanjut, Rahmawati dalam http://staffnew.uny.ac.id/upload/132296048/ pendidikan/Komunikasi++-Teknik+Presentasi+yang+Baik.pdf menyatakan bahwa kemampuan komunikasi meliputi penggunaan kata-kata, suara, dan bahasa tubuh, dapat menarik perhatian dan menampilkan diri.

Faktor-faktor tersebut sangat mempengaruhi penampilan presentasi. Faktanya, banyak mahasiswa pendidikan bahasa inggris FKIP Unikal masih mengalami kesulitan dalam hal presentasi. Kesulitan mereka anatara lain kurangnya penguasaan materi, penguasaan materi akan tetapi mempunyai kecemasan saat menyampaikan materi, sehingga hal tersebut dapat membuat mereka lupa akan materi. 


\section{METODE PENELITIAN}

Subjek penelitian ini adalah mahasiswa pendidikan bahasa inggris FKIP UNIKAL. populasi dalam penelitian ini adalah mahasiswa semester 2 dan 4 PBI FKIP Unikal tahun akademik 2016/2017. Pengambilan sampling berdasar random sampling dan menghasilkan sample sebesar 13 mahasiswa. Variable yang diteliti adalah motivasi berprestasi dan ketrampilan presentasi. Instrument yang digunakan adalah skala motivasi berprestasi dan lembar penilaian presentasi.

Desain penelitian ini menggunakan studi korelasi. Gay (dalam Sukardi, 2008:165) menyatakan bahwa penelitian korelasional merupakan salah satu bagian penelitian expostfacto karena peneliti tidak memberikan treatment atau memanipulasi variable dan hanya langsung mencari hubungan antara kedua variable yang direfleksikan dalam koefisien korelasi. Tujuan dari penelitian korelasi adalah untuk mencari adanya hubungan antara dua variable, kearah mana hubungan antara dua variable tersebut (positif/negative), dan seberapa jauh hubungan ada antara dua variabel. Lebih lagi, tujuan dari suatu penelitian korelasi adalah untuk menetapkan atau mengungkapkan suatu hubungan dalam membuat prediksi (prakiraan).

\section{HASIL DAN PEMBAHASAN}

Olah data dalam penelitian ini menggunakan SPSS. Analisis korelasi dua arah digunakan dalam penelitian ini. Berikut hasil analisis data.

\section{Correlations}

\begin{tabular}{|ll|r|r|}
\hline & \multicolumn{1}{|c|}{$\begin{array}{c}\text { Motivasi } \\
\text { Berprestasi }\end{array}$} & $\begin{array}{c}\text { Ketrampilan } \\
\text { Presentasi }\end{array}$ \\
\hline Motivasi Berprestasi & Pearson & 1 & $.413^{* *}$ \\
& Sig. (2-tailed) & & .000 \\
& $\mathrm{~N}$ & 71 & 71 \\
Ketrampilan & Pearson & $.413^{* *}$ & 1 \\
Presentasi & Correlation & .000 & \\
& Sig. (2-tailed) & 71 & 71 \\
\hline
\end{tabular}

**. Correlation is significant at the 0.01 level (2-tailed).

Dari tabel di atas dapat dilihat bahwa nilai signifikansi $0.000<0.005$ berarti terdapat korelasi yang signifikan. Dari output di atas diketahui bahwa Nilai Pearson Correlation yang dihubungkan antara masing-masing variabel mempunyai tanda bintang, ini berarti terdapat korelasi yang signifikan antara varibel yang dihubungkan.

Dari hasil analisis diatas menunjukan bahwa terdapat korelasi antara motivasi berprestasi dan ketrampilan presentasi. Hal ini dapat dilihat dari nilai sig. tailed correlation sebesar $0.000<0.005$. hasil analisis bernilai positif, hal ini berarti hubungan korelasi antara motivasi berprestasi dan kemampuan presentasi adalah positif. Artinya, semakin besar motivasi berprestasi, semakin besar kemampuan presentasi yang dimiliki oleh siswa, dan juga sebaliknya. 
Harga $\mathrm{r}$ (hubungan) dalam studi korelasi menurut (Cohen dan Manion 1981) dalam Sukardi (2008) dapat dibagi menjadi 4. Hal tersebut dapat dijelaskan sebagai berikut:

1. Hubungan dua variable lemah walaupun signifikan ditunjukan dengan nilai $\mathrm{r}=$ $0.20-0.35$

2. Hubungan dua variable yang sedang walau umumnya signifikan pada lebih dari $1 \%$, hubungan tersebut berguna untuk menganalisis prediksi dapat digambarkan dengan nilai $r=0.35-0.65$

3. Ketika hubungan antara dua variable cukup tinggi dan memungkinkan peneliti melakukan presiksi tepat, nilai $\mathrm{r}$ akan muncul pada 0.65-0.85.

4. Ketika nilai $\mathrm{r}=$ atau lebih besar dari 0.85 , hal ini menunjukkan hubungan yang tinggi antar variable.

Dari kutipan diatas, besaran korelasi antara kedua variable tersebut adalah 0.413 yang berarti ada hubungan yang sedang antara motivasi berprestasi dan ketrampilan presentasi. Nilai $\mathrm{r}$ menunjukan hasil yang positif. Yang artinya, semakin besar nilai variable motivasi berprestasi, semakin besar pula nilai untuk ketrampilan berprestasi. motivasi berprestasi mempunyai hubungan dan juga korelasi dengan ketrampilan berprestasi.

\section{SIMPULAN}

Dari hasil pembahasan dapat disimpulkan bahwa terdapat hubungan antara variable motivasi berprestasi dan ketrampilan presentasi. Hubungan tersebut bersifat positif, yaitu jika skor motivasi tinggi, maka ketrampilan motivasipun akan tinggi, begitu juga sebaliknya, jika skor motivasi rendah maka ketrampilan presentasi pun akan cenderung rendah. Dari hasil analisis didapat bahwa hubungan korelasi antara motivasi berprestasi dan ketrampilan presentasi adalah sedang.

\section{DAFTAR PUSTAKA}

Fitri Rahmawati. Teknik Presentasi yang Baik. http://staffnew.uny.ac.id/upload/132296048 /pendidikan/Komunikasi++Teknik+Presentasi+yang+Baik.pdf (diakses 4 November 2018)

Kay Alderman. 2004. Motivation for Achievement : Possibilities for teaching and learning. London : Lawrence Erlbaum Associates Producer.

C.S Dweck and D.C Molden. 2005. Self Theories. Their Impact on Competence Motivation and Acquisition. New York: Guilford Press

Hermayawati. 2010. Analisis Kesulitan Belajar Bahasa Inggris Mahasiswa. Jurnal SosioHumaniora, 1(1), 1-14.

M.C. McClelland. 1987. Human Motivation. New York: Cambridge University Press.

Sukardi. 2008. Metodologi Penelitian Pendidikan, Kompetensi dan Praktiknya. Jakarta : PT. Bumi Aksara.

W.S Grolnick, S.T Gurland, K.F. Jacob, \& W. Decourcey. 2002. The development of selfdetermination in middle childhood and adolescence. In Wigfield, A. \& Eccles, J.S. (Eds.). Development of Achievement Motivation (pp. 148-169). California: Academic Press An Elsevier Science Imprint. 